Original article

\title{
Environmental radioactivity in southern Serbia at locations where depleted uranium was used
}

\author{
Nataša B. Sarap, Marija M. Janković, Dragana J. Todorović, Jelena D. Nikolić, and \\ Milojko S. Kovačević \\ University of Belgrade, Vinča Institute of Nuclear Sciences, Radiation and Environmental Protection Department, \\ Belgrade, Serbia \\ Received in July 2013 \\ CrossChecked in February 2014 \\ Accepted in April 2014
}

\begin{abstract}
In the 1999 bombing of the Federal Republic of Yugoslavia, NATO forces used ammunition containing depleted uranium. The cleaning of depleted uranium that followed was performed in southern Serbia by the Vinča Institute of Nuclear Sciences between 2002 and 2007 at the locations of Pljačkovica, Borovac, Bratoselce, and Reljan. This paper presents detailed results of radioactivity monitoring four years after cleaning (2011), which included the determination of gamma emitters in soil, water, and plant samples, as well as gross alpha and beta activities in water samples. The gamma spectrometry results showed the presence of natural radionuclides ${ }^{226} \mathrm{Ra},{ }^{232} \mathrm{Th},{ }^{40} \mathrm{~K},{ }^{235} \mathrm{U},{ }^{238} \mathrm{U}$, and the produced radionuclide ${ }^{137} \mathrm{Cs}$ (from the Chernobyl accident). In order to evaluate the radiological hazard from soil, the radium equivalent activity, the gamma dose rate, the external hazard index, and the annual effective dose were calculated. Considering that a significant number of people inhabit the studied locations, the periodical monitoring of radionuclide content is vital.
\end{abstract}

KEY WORDS: environmental samples; gamma spectrometry; gross alpha activity; gross beta activity

Over the last 40 years, Europe has experienced several major radioactive fallouts, from atmospheric nuclear tests in North Africa during the 1960s, the Chernobyl accident in 1986, the Acerinox accident in 1998 to the wars in former Yugoslavia in the 1990s (1). Depleted uranium (DU) came into military use in the early 1990s and was first used in 1991 in the Gulf War $(2,3)$. The DU used during the wars in former Yugoslavia represents the most recent source of radioactivity released into the environment, following NATO air strikes (1, 4-6). NATO and Serbian Military (VS) data on DU use are in large discordance, but overlap for at least four locations $(5,6)$ in southern Serbia: Pljačkovica, Borovac, Bratoselce, and Reljan (Figure 1).

Uranium is a naturally occurring ubiquitous heavy metal found in various chemical forms in all soils, rocks, seas, and oceans. It is also present in drinking water and food. Natural uranium consists of a mixture of three different isotopes: ${ }^{238} \mathrm{U}$ $(99.27 \%),{ }^{235} \mathrm{U}(0.72 \%)$, and ${ }^{234} \mathrm{U}(0.0054 \%)$ (7). It is both chemically toxic and radioactive, and being water-soluble, it is easily taken up by plants, thus entering food chains and soil/water systems (8). Metallic uranium used for military purposes is practically insoluble in water and body fluids. However, while exposed to air and water, uranium is slowly oxidised to a +4 or +6 state (9).

The uranyl ion easily forms complexes, mainly carbonate $\left[\mathrm{UO}_{2}\left(\mathrm{CO}_{3}\right)_{2}\right]^{-2}$, which are well dissolved in water and body fluids. As the result of these chemical processes (weathering), uranium dispersed into the environment in a metallic form can slowly migrate to drinking water and plants and enter the 


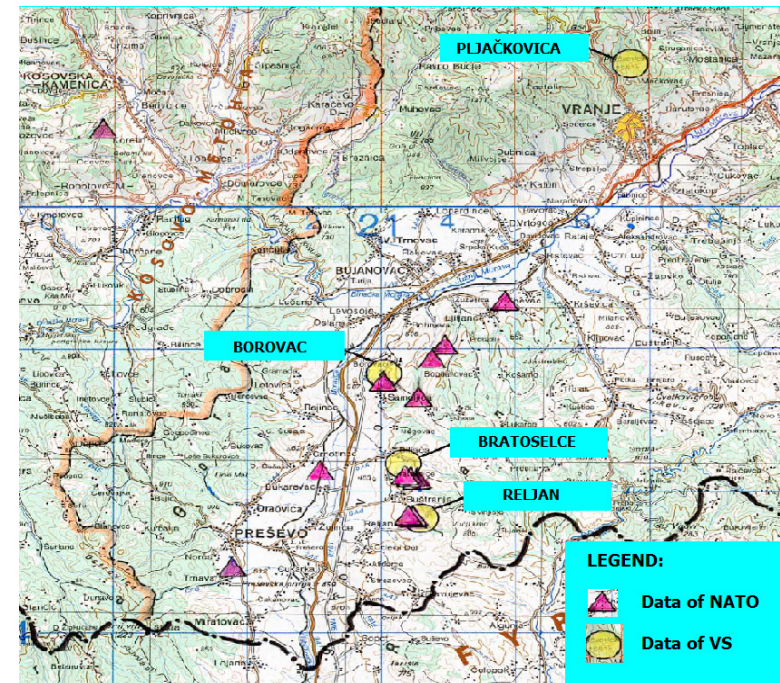

Figure 1 Information on locations in southern Serbia which are targeted depleted uranium. GPS coordinates of locations: Pljačkovica (420 34' 47" N; 210 53' 50" E), Borovac (420 23' 45" N; 210 45' 09" E); Bratoselce (420 $20^{\prime} 40^{\prime \prime}$ N; $21045^{\prime} 23^{\prime \prime}$ E); Reljan (420 18' 53" N; $21045^{\prime}$ $\left.58^{\prime \prime} E\right)$

human food chain. However, the weathering of DU penetrators strongly depends on the type of soil, its humidity and temperature (9). Depending on the physicochemical characteristics of the medium and chemical form in which uranium is bound, there are various scenarios for environmental contamination.

Quantitative determination of the DU fraction in environmental samples is difficult, primarily because of the relatively large content of natural uranium present in the environment. Based on the obtained concentrations of ${ }^{235} \mathrm{U}$ and ${ }^{238} \mathrm{U}$ and their ratio, a conclusion whether this ratio presents the natural activity ratio of uranium isotopes or possible presence of DU can be reached.

Considering the fact that people live and work on the locations examined here, it is necessary to periodically monitor the content of radionuclides in samples from these locations, especially because of the use of DU. Therefore, one of the aims of this study was to offer a detailed approach to perform such monitoring.

\section{MATERIALS AND METHODS}

\section{Environmental monitoring}

Regular radioactivity monitoring in Serbia includes spectrometric measurements of gamma emitters in soil, water and plant samples, as well as determination of the gross alpha and beta activities in water samples. The cleaning of DU left over after NATO air strikes, along with detailed dosimetric screening and decontamination, was performed by the Radiation and Environmental Protection Department of the Vinča Institute of Nuclear Sciences from 2002 to 2007 at Pljačkovica, Borovac, Bratoselce, and Reljan, located in southern Serbia, in coordination with the Agency for Radiation Protection and Nuclear Safety of Serbia (10) (Figure 1). Because of the loose soil at these locations, projectiles containing DU were found already at a depth of one meter. The discovered projectiles, contaminated soil, and all radioactive materials were disposed of as radioactive waste. After the cleaning, the terrain was aligned and another dosimetric screening was performed. In 2011, the Department collected and analysed samples from these locations in order to determine the activity concentrations of radionuclides and verify that the fields were successfully cleaned of DU.

\section{Sampling and sample preparation}

Soil samples were collected at 5 measuring points for each location (east, west, north, south, and centre) at a depth of 10-15 cm using a probe. The sampling depth was chosen based on the fact that these measurements follow the migration of radionuclides by depth (11). About $2 \mathrm{~kg}$ of samples were placed into polyethylene bags and transported to the laboratory. After removing the stones and vegetation, all soil samples were dried to $105^{\circ} \mathrm{C}$, sieved, placed in plastic $500 \mathrm{~mL}$ Marinelli beakers and left to reach radioactive equilibrium for four weeks (12).

The plant samples were taken differently and sampling included the presence of plant species (hay and grass). About $1 \mathrm{~kg}$ of samples was placed into polyethylene bags and transported to the laboratory. Plant samples were dried at room temperature over a few days, ashed at $450{ }^{\circ} \mathrm{C}$ during $24 \mathrm{~h}$, placed in plastic boxes of $100 \mathrm{~mL}$ and left to reach radioactive equilibrium for four weeks (12).

Water samples were taken from public fountains and wells from where the inhabitants draw water. These samples (20 L each) were collected directly from the springs in plastic bottles and tightly closed. For gamma spectrometric measurements, a volume of $17 \mathrm{~L}$ of water samples was acidified to $\mathrm{pH} 2$, evaporated to $200 \mathrm{~mL}$ under an infrared lamp, and then poured into $200 \mathrm{~mL}$ cylindrical polyethylene vials. The samples were then stored to reach radioactive equilibrium (12). For measurements of 
gross alpha and beta activity, a volume of $3 \mathrm{~L}$ of water samples was evaporated to dry residue under an infrared lamp. The remainder was heated to dryness at $450{ }^{\circ} \mathrm{C}(13,14)$. The residues were transferred quantitatively to a stainless-steel planchet and measurements were performed immediately after preparation.

Plant samples were concentrated by mineralisation and water samples by evaporation in order to maximize the detection efficiency, which is higher in geometries that are not collected in a large volume because the self-absorption effect is smaller.

\section{Procedure for gamma spectrometry}

Gamma spectrometric measurements were performed using HPGe Canberra detectors (Canberra Industries, Meriden, Connecticut, USA) with counting efficiency of 18 and $20 \%$. Due to the low activity in the samples and to reduce the uncertainty of measurement, the samples were measured $60,000 \mathrm{~s}$. The calibration of detectors for water and plant sample measurement was performed using a cylindrical polyethylene bottle of $200 \mathrm{~mL}$ and a plastic box of $100 \mathrm{~mL}$ in volume, respectively. This secondary reference material was obtained from the primary reference liquid radioactive material (9031OL-116/08, type ERX, Czech Metrological Institute, Prague, Czech Republic) spiked with a series of radionuclides $\left({ }^{241} \mathrm{Am},{ }^{109} \mathrm{Cd},{ }^{139} \mathrm{Ce},{ }^{57} \mathrm{Co},{ }^{60} \mathrm{Co},{ }^{88} \mathrm{Y}\right.$, ${ }^{113} \mathrm{Sn},{ }^{85} \mathrm{Sr},{ }^{137} \mathrm{Cs}$, and ${ }^{210} \mathrm{~Pb}$ ) with total activity of $114.9 \mathrm{kBq}$ on 3 March 2008. The calibration of detectors for measurement of soil samples was performed using a silicone resin matrix in the geometry of a plastic Marinelli beaker of $500 \mathrm{~mL}$ in volume, (9031-OL-208/08, type ERX, Czech Metrological Institute, Prague, Czech Republic) spiked with a series of radionuclides $\left({ }^{241} \mathrm{Am},{ }^{109} \mathrm{Cd}\right.$, ${ }^{139} \mathrm{Ce},{ }^{57} \mathrm{Co},{ }^{60} \mathrm{Co},{ }^{203} \mathrm{Hg},{ }^{88} \mathrm{Y},{ }^{113} \mathrm{Sn},{ }^{85} \mathrm{Sr}$, and ${ }^{137} \mathrm{Cs}$ ) with total activity of $40.624 \mathrm{kBq}$ on 15 April 2008.

The spectra were analysed using the program GENIE 2000 (Canberra Industries, Meriden, Connecticut, USA). The activity of ${ }^{226} \mathrm{Ra}$ and ${ }^{232} \mathrm{Th}$ was determined by their decay products: ${ }^{214} \mathrm{Bi}$ (609 keV, $1120 \mathrm{keV}$, and $1764 \mathrm{keV}),{ }^{214} \mathrm{~Pb}(295 \mathrm{keV}$ and $352 \mathrm{keV})$ and ${ }^{228} \mathrm{Ac}(338 \mathrm{keV}$ and $911 \mathrm{keV})$, respectively. ${ }^{235} \mathrm{U}$ was determined via $186 \mathrm{keV}$ corrected for ${ }^{226} \mathrm{Ra} .{ }^{238} \mathrm{U}$ was determined via ${ }^{234} \mathrm{Th}$ $(63 \mathrm{keV})$ or by ${ }^{234} \mathrm{~Pa}\left(\mathrm{t}_{1 / 2}=1.17 \mathrm{~min}, 1000 \mathrm{keV}\right)$. The activities of ${ }^{40} \mathrm{~K}$ and ${ }^{137} \mathrm{Cs}$ were determined from its $1460 \mathrm{keV}$ and $661 \mathrm{keV}$, respectively. The activities of ${ }^{210} \mathrm{~Pb}$ and ${ }^{7} \mathrm{Be}$ were determined from its $46 \mathrm{keV}$ and
$477 \mathrm{keV}$, respectively. The background spectrum was recorded regularly after or before the sample counting, with an empty $200 \mathrm{~mL}$ cylindrical polyethylene bottle, $100 \mathrm{~mL}$ plastic box, and $500 \mathrm{~mL}$ plastic Marinelli beaker.

The accuracy and reproducibility of gamma spectrometry systems were verified on weekly basis by a quality control $(\mathrm{QC})$ procedure. QC procedure consisted of the following steps: total background count rate was monitored to verify that the detector and shield have not been contaminated by radioactive materials; the total activity of the calibration source $\left[{ }^{60} \mathrm{Co}\right.$ and ${ }^{133} \mathrm{Ba}$ issued by the Czech Metrological Institute and traceable to BIPM (Bureau International des Poids et Measures)] was used to check the efficiency calibration and the general operating parameters of the gamma spectrometry system (source positioning, contamination, library values, and energy calibration); the detector-shield background, full energy peak efficiency, peak shape, and peak drift were measured to confirm whether they were within the warning and acceptance limits; the acceptance limits were set according to the manufacturer's specifications (peak shape and drift, full energy peak efficiency) and previous experiences (detector shield background); the specific activity of the radionuclides in the samples (A) was calculated using the equation:

$$
A=\frac{N}{t \times P_{\gamma} \times e f \times V(m)}
$$

where $N$ is count rate of the sample, $t$ - counting time (s), $P_{y}$ - probability of gamma decay (\%), ef - detector efficiency (\%), $V$ and $m$ are the volume (L) and mass $(\mathrm{kg})$ of the sample.

Minimum detectable activity (MDA) was calculated by the equation (2):

$$
M D A=\frac{L L D}{t \times P_{\gamma} \times e f \times V(m)}
$$

where $L L D$ isthe detectionlimit, $L L D=2.71+4.65 \sqrt{B}$ and B is background.

The combined measurement uncertainty of results was calculated at the $95 \%$ level of confidence $(\mathrm{k}=2)$.

Minimum detectable activity was inversely proportional to the measurement time of samples (equation 2), which is very important for spectrometry of gamma emitters in environmental samples. Also, in order to reduce the measurement uncertainty of the count rate below the photo peak of a certain energy that corresponds to radionuclides with low activities (such as ${ }^{235} \mathrm{U}$ ), it is necessary to increase the 
measurement time. Uncertainty measurement of count below the photo peak affects the overall uncertainty of the results, which can be calculated by the equation (3):

$$
\sigma=\sqrt{\left(\frac{\Delta N}{N}\right)^{2}+\left(\frac{\Delta t}{t}\right)^{2}+\left(\frac{\Delta P_{\gamma}}{P_{y}}\right)^{2}+\left(\frac{\Delta e f}{e f}\right)^{2}+\left(\frac{\Delta V(\Delta m)}{V(m)}\right)^{2}+\sigma_{n}{ }^{2}}
$$

where $\Delta / N$ is relative uncertainty of count which is corrected on background, $\Delta t / t$ relative uncertainty of time measurement, $\Delta P_{\gamma} / P_{\gamma}$ relative uncertainty of the gamma decay probability (table value), $\Delta$ eflef relative uncertainty of detector efficiency, $\Delta V / V(\Delta \mathrm{m} / \mathrm{m})$ relative uncertainty of volume determination (or mass determination), $\sigma_{n}$ uncertainty due to the fitting and due to the unfairness in the calibration.

\section{Procedure for gross alpha and gross beta activity}

Gross alpha and beta activity in water samples were determined by $\alpha / \beta$ low-level proportional counter Thermo Eberline FHT 770 T (ESM Eberline Instruments $\mathrm{GmbH}$, Erlangen, Germany). The counting time was 7,200 s.

Calibration was performed by using a standard source of ${ }^{90} \mathrm{Sr}$ (EM 145, Prague, Czech Republic) with an activity of $189.4 \mathrm{~Bq}$ on 1 August 2011 for beta activity and a standard source of ${ }^{241} \mathrm{Am}$ (EM 445, Prague, Czech Republic) with an activity of $224 \mathrm{~Bq}$ on the 1 August 2011 for alpha activity. The counting gas was a mixture of $90 \%$ argon and $10 \%$ methane. The counting efficiencies for the system were $26 \%$ for alpha and $35 \%$ for beta. The background of each detector was determined by counting an empty planchet for 3,600 s.

Quality of sampling and measurement and the calculated uncertainty are very important for predicting the dose for a population. The accuracy and reproducibility of a gas proportional counter were verified on a periodic basis (every week). Calibration was done every week with calibration standards and efficiency was checked. Total background count rate without a source was monitored to verify that the detector and shield have not been contaminated by radioactive materials. Alpha and beta efficiencies of gas proportional counter were checked with ${ }^{241} \mathrm{Am}$ and ${ }^{90} \mathrm{Sr}$ sources, respectively.

Gross alpha and beta activity was calculated using the following formula:

$$
A_{\alpha, \beta}=\frac{I}{V}
$$

where $A_{\alpha u \beta}$ is the activity of the sample $\left(\mathrm{Bq} \mathrm{L}^{-1}\right), V$ is the volume of the sample (L) that corresponds to the mass of solid residue, and $I$ is given by the formula:

$$
I=\frac{(N-B)}{e f}
$$

where $N$ is the count rate for the sample $\left(\mathrm{s}^{-1}\right), B$ is background $\left(\mathrm{s}^{-1}\right)$ and ef is the efficiency of the detectors for alpha and beta measurements.

Minimum detectable activity was calculated by the equation (6):

$$
M D A=\frac{L L D}{V}
$$

where $L L D$ is the detection limit $\left(\mathrm{s}^{-1}\right)$ and $V$ is the volume of the sample $(\mathrm{L})$. Measurement uncertainty determined as expanded measurement uncertainty was $30-40 \%$ for alpha and $15 \%$ for beta.

\section{Radium equivalent activity}

The distribution of ${ }^{226} \mathrm{Ra},{ }^{232} \mathrm{Th}$, and ${ }^{40} \mathrm{~K}$ in soil is not uniform. Uniformity with respect to exposure to radiation has been defined in terms of radium equivalent activity $\left(R a_{e q}\right)$ in $\mathrm{Bq} \mathrm{kg}{ }^{-1}$ to compare the specific activity of materials containing different amounts of ${ }^{226} \mathrm{Ra},{ }^{232} \mathrm{Th}$, and ${ }^{40} \mathrm{~K}(8)$. It is calculated using the following equation $(15,16)$ :

$$
R a_{e q}=A_{R a}+1.43 \times A_{T h}+0.077 \times A_{K}(7)
$$

where $A_{R a}, A_{T h}$, and $A_{K}$ are the specific activities of ${ }^{226} \mathrm{Ra},{ }^{232} \mathrm{Th}$, and ${ }^{40} \mathrm{~K}$ in $\mathrm{Bq} \mathrm{kg}{ }^{-1}$, respectively.

\section{Gamma dose rate calculation}

The external gamma dose rate in the air $1 \mathrm{~m}$ above ground level was calculated from the measured specific activities of ${ }^{226} \mathrm{Ra},{ }^{232} \mathrm{Th}$, and ${ }^{40} \mathrm{~K}$ in soil assuming that the other radionuclides, such as ${ }^{137} \mathrm{Cs}$, ${ }^{90} \mathrm{Sr}$, and the ${ }^{235} \mathrm{U}$ series, can be neglected as they contribute very little to the total dose from environmental background $(8,17)$. The calculations were performed according to the following equation (18):

$\dot{D}=0.462 \times A_{R a}+0.604 \times A_{T h}+0.042 \times A_{K}(8)$

where $\dot{D}$ is the dose rate in $\mathrm{nGy} \mathrm{h}^{-1}$.

\section{Calculation of external hazard index}

The external hazard index, $H_{e x}$, was defined as (15): 


$$
H_{e x}=\frac{A_{R a}}{370}+\frac{A_{T h}}{259}+\frac{A_{K}}{4810}
$$

The value of this index must be less than unity in order to keep the radiation hazard insignificant. The maximum value of $H_{e x}$ equal to unity corresponds to the upper limit of radium equivalent activity $\left(370 \mathrm{~Bq} \mathrm{~kg}^{-1}\right)(8)$.

\section{Calculation of annual effective dose}

To estimate the annual effective dose, the following must be taken into account: the conversion coefficient from absorbed dose in air to effective dose and the indoor occupancy factor (8). Using the dose rate data obtained from the concentration values of natural radionuclides in soil, adopting the conversion factor of $0.7 \mathrm{~Sv} \mathrm{~Gy}^{-1}$ (18) from the absorbed dose rate in air to the effective dose received by adults, and considering that people in Serbia on average spend $20 \%$ of their time outdoors, the annual effective doses were calculated by (8):

$$
D_{E}=0.7 \times 365 \times 24 \times 0.2 \times \dot{D}
$$

where $D_{E}$ is the annual effective dose in $\mathrm{nSv}$.

\section{RESULTS AND DISCUSSION}

The results of measurements of gamma emitters (mean activity concentrations) in soil samples collected at different locations in southern Serbia are presented in Table 1 along with a comparison with relevant literature. The activity concentrations of the radionuclides ranged between $16-102 \mathrm{~Bq} \mathrm{~kg}^{-1}$ for ${ }^{226} \mathrm{Ra}, 21-90 \mathrm{~Bq} \mathrm{~kg}{ }^{-1}$ for ${ }^{232} \mathrm{Th}, 184-979 \mathrm{~Bq} \mathrm{~kg}^{-1}$ for ${ }^{40} \mathrm{~K}, 2.9-19 \mathrm{~Bq} \mathrm{~kg}^{-1}$ for ${ }^{137} \mathrm{Cs}, 1.1-7.4 \mathrm{~Bq} \mathrm{~kg}^{-1}$ for ${ }^{235} \mathrm{U}$, and $21-95 \mathrm{~Bq} \mathrm{~kg}^{-1}$ for ${ }^{238} \mathrm{U}$.

The man-made radioisotope ${ }^{137} \mathrm{Cs}$, which has a generally negative impact on the environment, was identified in all of the samples and these values were in good agreement with those obtained in other regional studies $(8,19,20)$. From the late 1980s, most ${ }^{137} \mathrm{Cs}$ originates from the Chernobyl nuclear accident.

The highest concentrations of ${ }^{226} \mathrm{Ra},{ }^{40} \mathrm{~K},{ }^{137} \mathrm{Cs},{ }^{235} \mathrm{U}$, and ${ }^{238} \mathrm{U}$ were measured for Bratoselce, and the lowest for Borovac. Based on the measured concentrations of ${ }^{226} \mathrm{Ra},{ }^{232} \mathrm{Th}$, and ${ }^{40} \mathrm{~K}$, radium equivalent activity, gamma dose rate, external hazard index and annual effective dose are calculated and presented in Table
2 . The radium equivalent activity values for the soil samples varied from 60 to $260 \mathrm{~Bq} \mathrm{~kg}^{-1}$. These values were below the recommended level $\left(370 \mathrm{~Bq} \mathrm{~kg}^{-1}\right)(21)$. The mean gamma dose rate in air was calculated to be $78 \mathrm{nGy} \mathrm{h}^{-1}$ and was insignificantly higher than the global average $\left(57 \mathrm{nGy} \mathrm{h}^{-1}\right)(18)$. The calculated values of outdoor annual effective dose ranged from 0.03 to $0.15 \mathrm{mSv}$, which is close to the global average value $(0.07 \mathrm{mSv})(18)$. The external hazard index obtained in this study ranged from 0.16 to 0.70 . Since these values were lower than unity (18), we can conclude that the radiation hazard in the studied area was low.

The results of gamma emitter measurements in water samples from southern Serbia are presented in Table $3 .{ }^{226} \mathrm{Ra}$ was detected in all of the water samples, except for Bratoselce. ${ }^{40} \mathrm{~K}$ was detected in water samples from Pljačkovica and Reljan. The obtained values were low and mainly typical for water samples, while the activity concentrations for other radionuclides were below the detection limit.

The results on gross alpha and beta activity in the same water samples are presented in Table 4. Gross alpha activity ranged between $<\mathrm{MDA}-0.024 \mathrm{~Bq} \mathrm{~L}^{-1}$, while gross beta activity ranged from 0.07 to $0.36 \mathrm{~Bq} \mathrm{~L}^{-1}$. The obtained results showed that the natural activity concentrations of alpha and beta emitting radionuclides in water samples from southern Serbia were within recommended levels $(0.5$ and $1.0 \mathrm{~Bq} \mathrm{~L}^{-1}$, respectively) (22). The gross alpha activity (Table 4) was lower than the ${ }^{226} \mathrm{Ra}$ concentration in the tested samples (Table 3), as the determination of ${ }^{226} \mathrm{Ra}$ via daughters in cylindrical polyethylene bottle often leads to erroneous results. Gaseous Rn escapes from the water to a gaseous phase and remains partially present in the bottle, while its solid progenies ${ }^{214} \mathrm{Bi}$ and ${ }^{214} \mathrm{~Pb}$ can non-uniformly deposit on the walls of a bottle.

The results of gamma emitters in plant samples are presented in Table 5. In addition to the radionuclides already mentioned, the plant sample also revealed a presence of ${ }^{210} \mathrm{~Pb}$ and ${ }^{7} \mathrm{Be}$. The obtained results for ${ }^{210} \mathrm{~Pb}$ are characteristic for plant samples and higher than values for other natural radionuclides. This was expected because a plant can absorb ${ }^{210} \mathrm{~Pb}$ from soil and air. The activity concentrations of the radionuclides ranged between 1.8-4.5 $\mathrm{Bq} \mathrm{kg}^{-1}$ for ${ }^{226} \mathrm{Ra}, 2.1-$ $3.2 \mathrm{~Bq} \mathrm{~kg}^{-1}$ for ${ }^{232} \mathrm{Th}, 284-434 \mathrm{~Bq} \mathrm{~kg}^{-1}$ for ${ }^{40} \mathrm{~K},<\mathrm{MDA}-$ $1.3 \mathrm{~Bq} \mathrm{~kg}^{-1}$ for ${ }^{137} \mathrm{Cs}, 63-123 \mathrm{~Bq} \mathrm{~kg}^{-1}$ for ${ }^{7} \mathrm{Be}$, and 7-50 Bq kg-1 for ${ }^{210} \mathrm{~Pb}$. The obtained activity concentrations for ${ }^{235} \mathrm{U}$ and ${ }^{238} \mathrm{U}$ in plant samples from 
Table 1 Activity concentrations of radionuclides in soil samples in southern Serbia and comparison with literature $\left(B q \mathrm{~kg}^{-1}\right)$

\begin{tabular}{|c|c|c|c|c|c|c|c|}
\hline Location & ${ }^{226} \mathbf{R a}$ & ${ }^{232} \mathrm{Th}$ & ${ }^{40} \mathbf{K}$ & ${ }^{137} \mathrm{Cs}$ & ${ }^{235} \mathbf{U}$ & ${ }^{238} \mathbf{U}$ & ${ }^{235} \mathbf{U} /{ }^{238} \mathbf{U}$ \\
\hline Pljačkovica & $27 \pm 5$ & $32 \pm 4$ & $498 \pm 44$ & $14 \pm 1$ & $2.2 \pm 0.3$ & $33 \pm 7$ & 0.067 \\
\hline Borovac & $16 \pm 3$ & $21 \pm 3$ & $184 \pm 19$ & $3 \pm 1$ & $1.1 \pm 0.2$ & $21 \pm 5$ & 0.052 \\
\hline Bratoselce & $102 \pm 28$ & $58 \pm 6$ & $979 \pm 133$ & $19 \pm 2$ & $7.4 \pm 0.8$ & $95 \pm 18$ & 0.059 \\
\hline Reljan & $35 \pm 6$ & $90 \pm 11$ & $941 \pm 64$ & $5 \pm 1$ & $2.9 \pm 0.4$ & $49 \pm 12$ & 0.059 \\
\hline Average & 45 & 50 & 651 & 10 & 3.4 & 57 & / \\
\hline \multicolumn{8}{|c|}{ Comparison with literature } \\
\hline $\begin{array}{l}\text { Republic of } \\
\text { Srpska (8) }\end{array}$ & 47 & 41 & 536 & 26 & 3.4 & 64 & l \\
\hline Croatia (19) & 74 & 62 & 650 & 39 & 5.4 & 110 & / \\
\hline Slovenia (19) & 73.8 & l & 318 & 25.1 & l & 69.5 & l \\
\hline $\begin{array}{l}\text { Vojvodina } \\
\text { (Serbia) (20) }\end{array}$ & 40 & 53 & 554 & 12 & / & 51 & l \\
\hline World (18) & 35 & 30 & 400 & / & l & 35 & l \\
\hline
\end{tabular}

Table 2 Radium equivalent activity, gamma dose rate, annual effective dose, and external hazard index at four locations in southern Serbia

\begin{tabular}{|c|c|c|c|c|}
\hline Location & $\begin{array}{l}\text { Radium equivalent } \\
\text { activity (Bq kg-1) }\end{array}$ & $\begin{array}{l}\text { Gamma dose rate } \\
\qquad\left(\mathrm{nGy} \mathrm{h} \mathbf{h}^{-1}\right)\end{array}$ & $\begin{array}{c}\text { Annual effective } \\
\text { dose (mSv) }\end{array}$ & $\begin{array}{c}\text { External } \\
\text { hazard index }\end{array}$ \\
\hline Pljačkovica & 111 & 53 & 0.07 & 0.30 \\
\hline Borovac & 60 & 27 & 0.03 & 0.16 \\
\hline Bratoselce & 260 & 123 & 0.15 & 0.70 \\
\hline Reljan & 236 & 110 & 0.13 & 0.64 \\
\hline Average & 167 & 78 & 0.10 & 0.45 \\
\hline
\end{tabular}

Table 3 Activity concentrations of radionuclides in water samples from southern Serbia $\left(B q L^{-1}\right)$

\begin{tabular}{llcccccc}
\hline \multicolumn{2}{c}{ Location } & ${ }^{226} \mathbf{R a}$ & ${ }^{232} \mathbf{T h}$ & ${ }^{40} \mathbf{K}$ & ${ }^{137} \mathbf{C s}$ & ${ }^{235} \mathbf{U}$ & ${ }^{238} \mathbf{U}$ \\
\hline \multirow{2}{*}{ Pljačkovica } & Bazovnik & $<0.02$ & $<0.02$ & $<0.13$ & $<0.005$ & $<0.007$ & $<0.15$ \\
& draw well & $0.055 \pm 0.007$ & $<0.02$ & $0.17 \pm 0.03$ & $<0.005$ & $<0.007$ & $<0.15$ \\
\multirow{2}{*}{ Borovac } & house & $<0.02$ & $<0.02$ & $<0.13$ & $<0.005$ & $<0.007$ & $<0.15$ \\
& fountain & $0.033 \pm 0.005$ & $<0.02$ & $<0.13$ & $<0.005$ & $<0.007$ & $<0.15$ \\
\multirow{2}{*}{ Bratoselce } & courtyard 1 & $<0.02$ & $<0.03$ & $<0.13$ & $<0.004$ & $<0.009$ & $<0.12$ \\
& courtyard 2 & $<0.02$ & $<0.02$ & $<0.13$ & $<0.005$ & $<0.007$ & $<0.15$ \\
\multirow{2}{*}{ Reljan } & fountain & $0.018 \pm 0.003$ & $<0.02$ & $<0.13$ & $<0.004$ & $<0.009$ & $<0.15$ \\
& courtyard & $0.040 \pm 0.007$ & $<0.02$ & $0.15 \pm 0.03$ & $<0.005$ & $<0.007$ & $<0.15$ \\
\hline
\end{tabular}

Table 4 Gross alpha and gross beta activity concentrations of water samples from southern Serbia $\left(B q L^{-1}\right)$

\begin{tabular}{llcc}
\hline & Location & Gross alpha activity & Gross beta activity \\
\hline \multirow{2}{*}{ Pljačkovica } & Bazovnik & $0.009 \pm 0.001$ & $0.16 \pm 0.02$ \\
& draw well & $0.020 \pm 0.003$ & $0.29 \pm 0.04$ \\
\multirow{2}{*}{ Borovac } & house & $<0.006$ & $0.07 \pm 0.01$ \\
& fountain & $0.009 \pm 0.001$ & $0.09 \pm 0.01$ \\
Bratoselce & courtyard 1 & $<0.006$ & $0.30 \pm 0.05$ \\
& courtyard 2 & $<0.006$ & $0.29 \pm 0.04$ \\
Reljan & fountain & $<0.006$ & $0.11 \pm 0.02$ \\
& courtyard & $0.024 \pm 0.004$ & $0.36 \pm 0.05$ \\
\hline
\end{tabular}


Table 5 Activity concentrations of gamma emitters in plant samples from southern Serbia (Bq per kg of dry matter)

\begin{tabular}{ccccc}
\hline \multirow{2}{*}{ Radionuclide } & Pljačkovica & Borovac & Bratoselce & Reljan \\
\hline${ }^{226} \mathrm{Ra}$ & $1.8 \pm 0.2$ & $2.3 \pm 0.5$ & $4.5 \pm 0.7$ & $2.0 \pm 0.4$ \\
${ }^{232} \mathrm{Th}$ & $3.0 \pm 0.6$ & $3.2 \pm 0.6$ & $2.1 \pm 0.5$ & $3.2 \pm 0.8$ \\
${ }^{40} \mathrm{~K}$ & $434 \pm 43$ & $308 \pm 32$ & $284 \pm 31$ & $431 \pm 45$ \\
${ }^{137} \mathrm{Cs}$ & $1.0 \pm 0.1$ & $1.3 \pm 0.3$ & $<0.4$ & $0.8 \pm 0.2$ \\
${ }^{235} \mathrm{U}$ & $<0.3$ & $0.3 \pm 0.1$ & $<0.2$ & $0.3 \pm 0.1$ \\
${ }^{238} \mathrm{U}$ & $<4$ & $4.4 \pm 1.5$ & $<2.2$ & $3.5 \pm 1.4$ \\
${ }^{7} \mathrm{Be}$ & $123 \pm 12$ & $116 \pm 15$ & $108 \pm 10$ & $63 \pm 7$ \\
${ }^{210} \mathrm{~Pb}$ & $50 \pm 6$ & $32 \pm 4$ & $33 \pm 4$ & $7 \pm 2$ \\
\hline
\end{tabular}

Three plant samples were taken from each location

Pljačkovica and Bratoselce were below the detection limit.

\section{CONCLUSION}

The results of gamma spectrometric measurements of soil samples showed that the radioactivity levels in samples were similar to values characteristic for other locations in world where depleted uranium had not been used $(8,19,20,23-29)$.

According to the calculated values of external hazard index, there is no risk for the population living in the investigated area. Measurements of radioactivity in environmental samples at these locations in southern Serbia should, however, continue.

\section{Acknowledgement}

This work was partially supported by the Ministry of Education, Science and Technological Development of the Republic of Serbia, under Project no. III 43009.

\section{REFERENCES}

1. Esposito M, Polić P, Bartolomei P, Benzi V, Martellini M, Cvetković O, Damjanov V, Simić M, Žunić Z, Živančević B, Simić S, Jovanović V. Survey of natural and anthropogenic radioactivity in environmental samples from Yugoslavia. J Environ Radioact 2002;61:271-82. PMID: 14689992

2. Hamilton EI. Depleted uranium (DU): a holistic consideration of DU and related matters. Sci Total Environ 2001;281:5-21. PMID: 11778960

3. Bleise A, Danesi PR, Burkart W. Properties, use and health effects of depleted uranium (DU): a general overview. J Environ Radioact 2003;64:93-112. doi: 10.1016/S0265931X(02)00041-3

4. McLaughhlin JP, Vintro LL, Smith KJ, Mitchell PI, Žunić ZS. Actinide analysis of a depleted uranium penetrator from a 1999 target site in southern Serbia. J Environ Radioact 2003;64:155-65. PMID: 12500802

5. Radenković MB, Kandić AB, Vukanac IS, Joksić JD, Đorđević DS. Chemical and radiochemical characterization of depleted uranium in contaminated soils. Russ J Phys Chem A 2007;81:1448-51. doi: 10.1134/S0036024407090191

6. Radenković MB, Cupać SA, Joksić JD, Todorović DJ. Depleted uranium mobility and fractionation in contaminated soil (Southern Serbia). Env Sci Pollut Res 2008;15:61-7. PMID: 18306889

7. Betti M. Civil use of depleted uranium. J Environ Radioact 2003;64:113-9. PMID: 12500798

8. Janković M, Todorović D, Savanović M. Radioactivity measurements in soil samples collected in the Republic of Srpska. Radiat Meas 2008;43:1448-52. doi: 10.1016/j. radmeas.2008.03.004

9. Bem H, Bou-Rabee F. Environmental and health consequences of depleted uranium use in the 1991 Gulf War. Environ Int 2004;30:123-34. PMID: 14664872

10. Agency for Radiation Protection and Nuclear Safety of Serbia. Rulebook: On radioactivity monitoring. Official Gazette of the Republic of Serbia: 97/2011; 2011.

11. Todorović D, Kovačević M. Study of investigation of radionuclides content in environmental at locations where depleted uranium was used. Vinča Institute of Nuclear Sciences: Belgrade, Serbia; 2011.

12. HASL-300. The EML Procedures Manual. New York: Environmental Measurements Laboratory; 1983.

13. International Atomic Energy Agency (IAEA). Measurements of Radionuclides in Food and the Environment. Technical Report Ser. No. 295. Vienna: IAEA; 1989.

14. United States Environmental Protection Agency (US EPA). Prescribed Procedures for Measurement of Radioactivity in Drinking Water. EPA-600/4-80-032, Method 900.0.; 1980 [displayed 27 March 2014]. Available at http://www.health. state.mn.us/divs/phl/accreditation/docs/ refeparadioactivitydw.pdf

15. Beretka J, Mathew PJ. Natural radioactivity of Australian building materials, industrial wastes and by-products. Health Phys 1985;48:87-95. doi: 10.1097/00004032-19850100000007

16. Yu KN, Guan ZJ, Stokes MJ, Young ECM. The assessment of the natural radiation dose committed to the Hong Kong people. J Environ Radioact 1992;17:31-48. doi: 10.1016/0265-931X(92)90033-P 
17. Kocher DC, Sjoreen AL. Dose-rate conversion factors for external exposure to photon emitters in soil. Health Phys 1985;48:193-205. PMID: 3972585

18. United Nations Scientific Committee on the Effects of Atomic Radiation (UNSCEAR). Sources and effects of ionising radiation. Report of the United Nations Scientific Committee on the Effects of Atomic Radiation to the General Assembly, 2008 [displayed 27 March 2014]. Available at http://www. unscear.org/docs/reports/2008/09-86753_Report_2008_ Annex_B.pdf

19. Vaupotič J, Barišić D, Kobal I, Lulić S. Radioactivity and radon potential of the terra rossa soil. Radiat Meas 2007;42:290-7. doi: 10.1016/j.radmeas.2007.01.034

20. Bikit I, Slivka J, Čonkić Lj, Krmar M, Vesković M, ŽikićTodorović N, Varga E, Ćurčić S, Mrđa D. Radioactivity of the soil in Vojvodina (northern province of Serbia and Montenegro). J Environ Radioact 2005;78:11-9. doi: 10.1016/j.jenvrad.2004.03.034

21. Organization for Economic Cooperation and Development (OECD). Exposure to radiation from the natural radioactivity in building materials. Report by a Group Experts of the OECD Nuclear Energy Agency, 1979 [displayed 27 March 2014]. Available at https://www.oecd-nea.org/rp/ reports/1979/exposure-to-radiation-1979.pdf.

22. Official Gazette of the Republic of Serbia Rulebook: On limits of radionuclides content in drinking water, foodstuffs, feeding stuffs, medicines, general use products, construction materials and other goods that are put on market. 86/2011; 2011.
23. Saleh $\mathrm{H}, \mathrm{Abu}$ Shayeb M. Natural radioactivity distribution of southern part of Jordan (Ma'an) Soil. Ann Nucl Energy 2014;65:184-9.

24. Lu X, Zhao C, Chen C, Liu W. Radioactivity level of soil around Baqiao coal-fired power plant in China. Radiat Phys Chem 2012;81:1827-32. doi: 10.1016/j. radphyschem.2012.07.013

25. Montes ML, Mercader RC, Taylor MA, Runco J, Desimoni J. Assessment of natural radioactivity levels and their relationship with soil characteristics in undisturbed soils of the northeast of Buenos Aires province, Argentina. J Environ Radioact 2012;105:30-9. doi: 10.1016/j.jenvrad.2011.09.014

26. Bolca M, Sac MM, Cokuysal B, Karali T, Ekdal E. Radioactivity in soils and various foodstuffs from the Gediz River Basin of Turkey. Radiat Meas 2007;42:263-70.

27. Santawamaitre T, Malain D, Al-Sulaiti HA, Matthews M, Bradley DA, Regan PH. Study of natural radioactivity in riverbank soils along the Chao Phraya river basin in Thailand. Nucl Instr Meth A 2011;652:920-24. doi: 10.1016/j. nima.2010.10.057

28. Mohery M, Baz S, Kelany AM, Abdallah AM. Environmental radiation levels in soil and sediment samples collected from floating water from a land runway resulting from heavy rains in the Jeddah region, KSA. Radiat Phys Chem 2014;97:1624. doi: 10.1016/j.radphyschem.2013.10.007

29. El Samad O, Baydoun R, Nsouli B, Darwish T. Determination of natural and artificial radioactivity in soil at North Lebanon province. J Environ Radioact 2013;125:36-9. doi: 10.1016/j. jenvrad.2013.02.010 


\section{Sažetak}

\section{Radioaktivnost u životnoj sredini južne Srbije na lokacijama na kojima je korišten osiromašeni uran}

U napadu na Saveznu Republiku Jugoslaviju 1999. godine NATO-ove su snage koristile municiju s osiromašenim uranom. Od 2002. do 2007. Laboratorij za zaštitu od zračenja i zaštitu životne sredine Instituta Vinča proveo je akciju čišćenja osiromašenog urana na lokacijama Pljačkovica, Borovac, Bratoselce i Reljan. U ovom se radu iznose detaljni rezultati praćenja radioaktivnosti u južnoj Srbiji četiri godine nakon spomenute akcije čišćenja (2011), koji uključuje određivanje gama zračenja u uzorcima zemljišta, vode i biljki te određivanje ukupne alfa i beta aktivnosti u uzorcima vode. Rezultati gama spektrometrije pokazali su prisutnost prirodnih radionuklida: ${ }^{226} \mathrm{Ra},{ }^{232} \mathrm{Th},{ }^{40} \mathrm{~K},{ }^{235} \mathrm{U},{ }^{238} \mathrm{U}$ i proizvedenog radionuklida ${ }^{137} \mathrm{Cs}$. Za procjenu radijacijskog rizika iz zemljišta izračunati su ekvivalent radija, brzina apsorbirane doze gama zračenja, indeks radijacijskog rizika uslijed vanjskog izlaganja i efektivna doza zračenja. Imajući u vidu da na ispitivanim područjima živi znatan broj ljudi, iznimno je važno da se ondje periodično prati sadržaj radionuklida.

KLJUČNE RIJEČI: uzorci iz životne sredine; gama spektrometrija; ukupna alfa aktivnost; ukupna beta aktivnost

\section{CORRESPONDING AUTHOR:}

\section{Nataša B. Sarap}

University of Belgrade, Institute Vinča,

Radiation and Environmental Protection Department, Mike Petrovića Alasa 12-14, 11001 Belgrade, Serbia E-mail:natasas@vinca.rs 